\title{
ANALISIS PERUBAHAN POLA PIKIR DAN SIKAP TOKOH KABUL DALAM NOVEL ORANG-ORANG PROYEK KARYA AHMAD TOHARI
}

\author{
Oleh :
}

\section{PATRISIA CUESDEYENI dan RENY YULIANTI MAYANG}

\begin{abstract}
Abstrak
Penelitian yang berjudul —Analisis Perubahan Pola Pikir dan Sikap Tokoh Kabul dalam Novel Orang-Orang Proyek Karya Ahmad Toharill bertujuan untuk mendeskripsi-kan perubahan pola pikir dan sikap tokoh dalam novel yang dapat dijadikan contoh dan digunakan untuk meningkatkan kemampuan menganalisis unsur intrinsik dan ekstrinsik novel Indonesia.

Penelitian ini menggunakan pendekatan kualitatif; data kualitatif--tentang kaidah stratifikasi sosial, yang terdapat dalam sumber penelitian yaitu novel Orang-Orang Proyek karya Ahmad Tohari, yang berupa gambaran perubahan pola pikir dan sikap tokoh utama--; wujud data kualitatif dalam penelitian ini ialah kutipan-kutipan yang berkaitan dengan perubahan pola pikir dan sikap tokoh Kabul dalam bentuk kata, kalimat, dan paragraf; teknik pengumpulan data yang digunakan adalah teknik dokumentasi; teknik analisis: mendeskripsikan, menganalisis, meninjau ulang, menyimpulkan, dan memaparkan hasil penelitian.
\end{abstract}

Hasil penelitian menunjukkan bahwa terdapat delapan data perubahan pola pikir dan tujuh data perubahan sikap tokoh Kabul dalam novel Orang-Orang Proyek karya Ahmad Tohari. Kelima belas data ini dapat digunakan sebagai contoh dalam pembelajaran.

Kata Kunci: Perubahan, pola pikir, sikap, tokoh utama

\section{PENDAHULUAN}

Sastra adalah suatu bentuk dari hasil pekerjaan seni kreatif yang objeknya adalah manusia dan kehidupannya dengan menggunakan bahasa sebagai medianya. Sebagai sebuah bentuk kesenian yang berobjek manusia dengan segala macam permasalahan kehidupannya, maka ia tidak saja merupakan suatu media untuk menyampaikan ide, teori atau sistem berpikir manusia, melainkan sastra harus pula mampu menjadi wadah penyampaian ide-ide yang dipikirkan sastrawan tentang kehidupan manusia (Semi, dalam Riawati, 2010: 1).

Sastra sebagai seni merupakan kegiatan kreatif menghasilkan sesuatu berupa puisi, novel, cerita pendek, dan drama. Seni sastra atau kesusastraan ialah kegiatan seni yang mempergunakan bahasa dan simbol lain sebagai alat penyampaian ide serta bersifat imajinasi sastra.

Aminuddin (2000: 37) mengungkapkan bahwa sifat sastra, selain menyajikan nilainilai keindahan serta paparan peristiwa yang mampu memberikan kepuasan batin pembacanya, juga mengandung pandangan yang berhubungan dengan renungan batin, baik berhubungan dengan masalah keagamaan, filsafat, politik, maupun berbagai macam problem yang berhubungan dengan kompleksitas dalam lingkup kehidupan ini. 
Cerita yang tertuang ke dalam karya fiksi terdapat realitas sosial yang mengacu pada masalah-masalah dalam masyarakat itu sendiri. Karya sastra menerima pengaruh dari masyarakat (Semi, 1990: 73). Sastra dapat dikatakan sebagai cerminan masyarakat, tetapi tidak berarti struktur masyarakat seluruhnya tergambarkan dalam sastra, yang didapat di dalamnya adalah gambaran masalah masyarakat secara umum ditinjau dari sudut lingkungan tertentu yang terbatas dan berperan sebagai mikrokosmos sosial dan diteliti dengan sudut pandang sosiologis.

Penelitian yang menggunakan pendekatan sosiologis terhadap karya sastra, merupakan studi yang ilmiah dan objektif mengenai manusia dalam masyarakat, studi mengenai lembagalembaga dan proses-proses sosial. Gambaran ini akan menjelaskan cara- cara manusia menyesuaikan diri dengan ditentukan oleh masyarakat-masyarakat tertentu, gambaran mengenai mekanisme sosialisasi, proses belajar secara kultural, dengan individu- individu yang dialokasikan pada dan menerima peranan-peranan tertentu dalam struktur sosial.

Alasan peneliti memilih novel sebagai bahan penelitian karena novel membahas dan melukiskan realitas yang dilihat dan dirasakan dalam bentuk tertentu dengan pengaruh atau ikatan yang dihubungkan dengan tercapainya gerak-gerik hasrat manusia. Novel juga bersifat imajinatif, menceritakan kehidupan manusia hingga terjadinya konflik yang dapat menyebabkan perubahan nasib bagi pelakunya.

Penelitian tentang perubahan pola pikir dan sikap tokoh Kabul dalam novel OrangOrang Proyek karya Ahmad Tohari merupakan hal penting bagi siswa dalam pencapaian kompetensi dasar pembelajaran apresiasi sastra. Hal ini disebabkan siswa akan mempunyai bahan dalam meningkatkan pengetahuan dan pengalamannya dalam menganalisis unsur- unsur intrinsik dalam novel, khususnya hal yang berkaitan dengan amanat. Hal-hal yang disajikan dalam novel biasanya diangkat dari kisah kehidupan sehari-hari yang berkaitan dengan realitas sosial. Melalui penelitian ini siswa akan menemukan gambaran mengenai perubahanperubahan yang ditimbulkan dan akan memperoleh wawasan berpikir kritis tentang perubahan sosial yang terjadi dalam kehidupan sehari-hari.

Penelitian ini difokuskan pada gambaran perubahan pola pikir dan sikap yang dialami tokoh Kabul dalam novel Orang-Orang Proyek karya Ahmad Tohari. Pemilihan judul penelitian ini didasarkan dengan alasan berikut.

1. Perubahan pola pikir dan sikap merupakan salah satu unsur pembangun dalam unsur intrinsik, salah satu unsur pembangun cerita dalam sebuah karya fiksi serta berkaitan dengan unsur ekstrinsik karena pada perubahan pola pikir dan sikap mengarah pada nilai-nilai sosial yang ditimbulkan.

Alasan pemilihan novel Orang-Orang Proyek karya Ahmad Tohari, yaitu

(1) menyajikan permasalahan sosial yang terjadi di kehidupan sehari-hari dan sarat akan nilai kritik sosial sehingga memudahkan menjadi bahan analisis, dan (2) menyajikan berbagai permasalahan yang menarik dan berhubungan dengan kritik sosial masyarakat serta sarat akan pesan moral.

Alasan pemilihan karya Ahmad Tohari dalam penelitian ini adalah (1) Ahmad Tohari adalah sastrawan yang selalu memandang masalah sosial sebagai pusat inspirasi. Ia intens membahas tema-tema sosial dalam setiap karyanya. Ia tidak menyetujui adanya suatu tindakan yang menyebabkan ketimpangan sosial dalam masyarakat, (2) beberapa karya fiksinya antara lain trilogi Ronggeng Dukuh Paruk telah terbit dalam edisi 
Jepang, Jerman, Belanda, dan Inggris, dan (3) Ahmad Tohari menerima Hadiah Sastra Asean, Sea Write Award.

Penelitian ini difokuskan pada: (1) bagaimana gambaran perubahan pola pikir pada tokoh Kabul dalam Novel Orang-Orang Proyek karya Ahmad Tohari? (2) Bagaimana gambaran perubahan sikap pada tokoh Kabul dalam Novel Orang-Orang Proyek karya Ahmad Tohari? Dengan demikian, penelitian ini bertujuan untuk (1) memperoleh deskripsi tentang perubahan pola pikir tokoh Kabul dalam novel Orang-Orang Proyek karya Ahmad Tohari, dan (2) memperoleh deskripsi tentang perubahan sikap tokoh Kabul dalam novel Orang-Orang Proyek karya Ahmad Tohari. Kedua deskripsi ini dapat dijadikan contoh dan digunakan untuk meningkatkan kemampuan menganalisis unsur intrinsik dan ekstrinsik novel Indonesia.

Penelitian ini menggunakan pendekatan kualitatif. Pendekatan kualitatif adalah pendekatan yang terurai dalam bentuk kata-kata atau gambaran bukan dalam bentuk angkaangka. Data penelitian ini adalah data yang berkaitan dengan objek penelitian, yakni data tentang kaidah stratifikasi sosial yang terdapat dalam novel Orang-Orang Proyek karya Ahmad Tohari. Adapun data yang dimaksud adalah gambaran perubahan pola pikir dan sikap tokoh utama. Sumber data penelitian adalah perubahan pola pikir dan sikap ini ialah novel OrangOrang Proyek karya Ahmad Tohari, yang diterbitkan oleh PT. Gramedia Pustaka Utama pada tahun 2007. Wujud data kualitatif dalam penelitian ini ialah kutipan-kutipan yang berkaitan dengan perubahan pola pikir dan sikap tokoh Kabul dalam bentuk kata, kalimat, dan paragraf yang berhubungan dengan aspek penelitian, yakni gambaran perubahan pola pikir dan sikap tokoh utama dalam novel Orang-Orang Proyek.

Teknik pengumpulan data yang digunakan adalah teknik dokumentasi. Langkah yang ditempuh adalah (1) mengumpulkan data yang akan diteliti; (2) membaca dengan cermat secara keseluruhan dan menandai bagian-bagian yang diperlukan untuk memperoleh data yang diinginkan berupa perubahan pola pikir dan sikap tokoh Kabul dalam novel Orang- Orang Proyek karya Ahmad Tohari; (3) mengklasifikasikan hasil pencatatan ke dalam beberapa bagian sesuai dengan fokus penelitian: (a) gambaran perubahan pola pikir tokoh Kabul dalam novel Orang-Orang Proyek karya Ahmad Tohari dan (b) perubahan sikap tokoh Kabul dalam novel Orang-Orang Proyek karya Ahmad Tohari; (4) hasil dari pencatatan pengklasifikasian tersebut merupakan data yang siap dianalisis; (5) memaparkan hasil penelitian secara lengkap dalam bentuk tertulis, setelah memberikan hasil simpulan tentang hasil deskripsi.

Teknik analisis data dalam penelitian ini adalah melalui beberapa langkah (1) mendeskripsikan data perubahan pola pikir tokoh Kabul dalam novel Orang-Orang Proyek, (2) mendeskripsikan data perubahan sikap tokoh Kabul dalam novel Orang-Orang Proyek,

(3) melakukan analisis terhadap data perubahan pola pikir dan sikap tokoh Kabul dalam novel Orang-Orang Proyek karya Ahmad Tohari, (4) mengadakan peninjauan ulang terhadap hasil analisis perubahan pola pikir dan sikap tokoh Kabul dalam novel Orang-Orang Proyek,

(5) memberikan simpulan tentang hasil deskripsi dan analisis, (6) memaparkan hasil penelitian secara lengkap dalam bentuk tertulis. 


\section{Hasil dan Pembahasan}

Pembahasan terfokus pada perubahan sosial tokoh Kabul dalam novel Orang-Orang Proyek karya Ahmad Tohari. Perubahan sosial ini mengarah pada dua hal, yaitu perubahan pola pikir dan perubahan sikap. Pola pikir yang didasarkan intuisi, deduktif, dan induktif, sedangkan perubahan sikap yang didorong oleh faktor eksternal dan internal. Kedua hal tersebut diungkap berikut ini.

\section{Perubahan Pola pikir Tokoh Kabul dalam Novel Orang-Orang Proyek Karya Ahmad Tohari}

Perubahan pola pikir adalah peralihan yang menjadi acuan utama seseorang untuk bertindak karena adanya suatu perubahan yang berasal dari pola pikirnya. Selanjutnya dikatakan bahwa pola pikir adalah pola yang menetap dalam pikiran bawah sadar seseorang.

Perubahan pola pikir terdapat pada kutipan novel Orang-Orang Proyek karya Ahmad Tohari sebagai berikut.

-Dan Wati sering membawakan majalah kesukaan Kabul, karena kebetulan Kabul tak sempat pergi ke kota. Pernah sesekali Wati mengajaknya nonton di kota dan Kabul tak kuasa untuk menolak ajakannya. Namun setidaknya Kabul bisa menahan diri ketika malam minggu kemarin Wati kembali mengajaknya nonton film ke kota.

-Aku memang suka nonton, Wat. Tetapi maaf, untuk nonton berdua sama kamu aku khawatir akan dikatakan kurang pantas.॥

-Mas malu nonton sama aku kan?\| Tanya Wati

-Kamu pasti tahu alasan saya; bagaimana nanti perasaan pacar kamu. Mak Sumeh betul kan, kamu sudah punya pacar?"

(Ahmad Tohari, hlm. 99)

Perubahan pola pikir berdasarkan intuisi oleh tokoh Kabul ditunjukkan pada kalimat: Kabul tak kuasa untuk menolak ajakannya. Kalimat tersebut menunjukkan bahwa Kabul tak dapat menolak ajakan Wati karena di satu sisi ia juga mengakui bahwa perhatian tersebut membuatnya nyaman. Namun, ketika Wati ingin kembali mengajaknya nonton berdua, Kabul dapat menahan dirinya karena mendekati perempuan yang sudah memiliki kekasih pantang baginya. Walaupun, sebenarnya ia juga menyukai perempuan tersebut, namun bertentangan dengan pola pikirnya yang ditunjukkan pada kalimat: Kabul bisa menahan diri.

Kalimat yang juga menunjukkan perubahan pola pikir Kabul yaitu: kamu pasti tahu alasan saya; bagaimana nanti perasaan pacar kamu. Mak Sumeh betul kan, kamu sudah punya pacar? tersebut menyatakan intuisi Kabul yang tidak mau mengganggu hubungan Wati dan kekasihnya. Intuisi merupakan cara berpikir yang didasarkan atas perasaan, rasa, atau emosi. Istilah lain dari intuisi adalah kecerdasan hati. Kabul tetap pada pemikirannya bahwa mendekati perempuan yang sudah memiliki kekasih merupakan hal yang lancang dan dapat merusak hubungan orang lain. Ia membiarkan perubahan tersebut yang menjadi landasan utamanya untuk menolak ajakan Wati, walau sebenarnya ia menginginkannya.Ia tetap berpegang pada pemikirannya yang dilandasi dengan intuisi tersebut agar tidak ada pihak yang menjadi sakit hati dengan perbuatannya. 
-Awalnya, aku mampu menguraikan dengan benar hubungan disiplin ilmu yang ku dapatkan di bangku kuliah. berharap kejujuran dan kesungguhan yang nantinya dapat kuterapkan dalam proyek yang kutangani.\|

-Aku insinyur. Aku tak bisa menguraikan dengan baik hubungan antara kejujuran dan kesungguhan dalam pembangunan proyek ini dengan keberpihakan kepada masyarakat miskin. Apakah yang pertama merupakan manifestasi yang kedua? Apakah kejujuran dan kesungguhan sejatinya adalah perkara yang biasa bagi masyarakat berbudaya, dan harus dipilih karena keduanya hal yang niscaya untuk menghasilkan kemaslahatan bersama? Mungkin. Atau entah. Yang jelas bagiku kecurangan besar maupun kecil yang terjadi di proyek ini pasti akan mengurangi tingkat kesungguhan, bahkan mengkhianati tujuan dasarnya. Dan hatiku tak bisa menerimanya.॥

(Ahmad Tohari, hlm. 34)

Kutipan novel di atas menunjukkan bentuk perubahan pola pikir tokoh Kabul yang ditandai dengan kalimat: aku mampu menguraikan dengan benar hubungan disiplin ilmu yang ku dapatkan di bangku kuliah. Bentuk perubahan ditunjukkan pada kalimat: Aku tak bisa menguraikan dengan baik hubungan antara kejujuran dan kesungguhan dalam pembangunan proyek ini. Kalimat tersebut menunjukkan pola pikir Kabul yang berbeda saat masih menempuh kuliah hingga menjadi seorang insinyur sipil. Jika dulu ia berpikir bahwa semua hal yang berkaitan dengan ketidakadilan dapat diatasi, maka ia pun mulai mengubah pemikirannya bahwa teori dan realita sangat berbeda.

Kalimat: Keberpihakan kepada masyarakat miskin. Apakah yang pertama merupakan manifestasi yang kedua? menunjukkan peralihan pemikirannya terhadap kenyataan yang dialami dalam lingkungan sosialnya. Ditambah lagi dengan kalimat yang menyatakan: mungkin. Atau entah. Yang jelas bagiku kecurangan besar maupun kecil yang terjadi di proyek ini pasti akan mengurangi tingkat kesungguhan, bahkan mengkhianati tujuan dasarnya tersebut menunjukkan perubahan pola pikir tokoh Kabul yang didasarkan atas intuisi. Terkaan Kabul selama ini yang menganggap bahwa proyek itu bersih dari korupsi ternyata ia harus mengubah pola pikir dan pastinya akan berdampak pada sikapnya.

Intuisi yang dirasakan Kabul sehingga mengubah pola pemikirannya merupakan luapan perasaannya atas realita sosial yang dihadapi saat ini, ditunjukkan pula pada kutipan berikut.

-Tapi kerusakan itu kan akibat banjir. Banjir adalah urusan alam, jadi untuk apa disesali dan sedih? Toh pekerjaan bisa di ulang lagi. Tapi tetap saja, kerusakan itu membuat kerugian yang cukup besar. Serta memberi beban batin karena hasil kerja beberapa hari dengan biaya jutaan lenyap seketika.l

-Karena kerugian itu sesungguhnya bisa dihindarkan bila awal pelaksanaan pembangunan jembatan ditunda sampai musim kemarau tiba beberapa bulan lagi. Itulah rekomendasi dari para perancang. Namun rekomendasi itu diabaikan, konon demi mengejar waktull.

(Ahmad Tohari, hlm.10) 
Pola pikir yang dialami Kabul ditunjukkan pada kalimat: banjir adalah urusan alam, jadi untuk apa disesali dan sedih? Toh pekerjaan bisa di ulang lagi. Kutipan tersebut menunjukkan bahwa Kabul awalnya tidak mau mengambil pusing atas kerusakan yang terjadi. Namun, Kabul tidak dapat menyembunyikan kesedihannya, sehingga bentuk perubahan pola pikir ditunjukkan pada kalimat: kerusakan itu membuat kerugian yang cukup besar. Serta memberi beban batin.

Kalimat: Membuat kerugian yang cukup besar merupakan dampak yang dipikirkan akibat pengerjaan proyek yang tidak sesuai dengan waktunya. Hal itulah yang memberi tekanan batin pada tokoh Kabul sehingga membuatnya berpikir secara deduktif dan ditunjukkan pada kalimat: Kerugian itu sesungguhnya bisa dihindarkan bila awal pelaksanaan pembangunan jembatan ditunda sampai musim kemarau tiba beberapa bulan lagi. Itulah rekomendasi dari para perancang.

Pola pikir deduktif adalah cara menarik kesimpulan khusus dari hal-hal yang bersifat umum. Kesimpulan deduktif dibentuk dengan cara deduksi ,yakni dimulai dari hal-hal yang umum menuju pada hal-hal yang khusus. Proses pembentukan kesumpulan deduktif tersebut dapat dimulai dari suatu dalil menuju pada hal-hal yang konkrit.

Ilmu yang didapatkan oleh Kabul sewaktu kuliah sulit ia terapkan di lingkungan proyek yang dikerjakannya saat ini sehingga membuatnya harus mengubah pemikirannya agar jembatan tersebut selesai dengan waktu yang ditentukan walau tidak sesuai dengan rekomendasi perancang. Perubahan pemikirannya tersebut tidak sesuai dengan hati nurani dan ilmu yang dilakukannya, sehingga dengan terpaksa ia harus mengikutinya.

-Semasa kuliah, Kabul sangat prihatin terhadap orang-orang yang memiliki gaya hidup pragmatis. Melihat teman kampus yang selalu memamerkan harta yang diyakini sebagai harta orang tua, membuat ia kasihan bahkan mencoba mendekati untuk memberi pengertian tentang kerugian yang akan dihadapi. Sikap Kabul tersebut membuatnya dianggap sebagai orang yang munafik oleh beberapa teman sekampusnya.\|

-Kabul memang sudah tahu gaya hidup atasan dan keluarganya itu. Pragmatis, jor-joran. Hidup harus dinikmati atau mencari nikmat dalam hidup. Ah, itu jalan yang dipilih koboi Dalkijo. Itu urusan dia. Namun masalahnya, dalam ceramah tadi, Dalkijo secara tak langsung menyindir jalan lain yang sudah dipilihnya. Bagi Kabul, kemiskinan memang harus dihilangkan. Namun tidak harus dengan dendam pribadi . dan karena kemiskinan terkait erat dengan struktur maupun kultur masyarakat, menghilangkannya harus melibatkan semua orang dalam semangat setia kawan yang tinggi.

(Ahmad Tohari, hlm.31-32)

Kalimat: melihat teman kampus yang selalu memamerkan harta yang diyakini sebagai harta orang tua, membuat ia kasihan bahkan mencoba mendekati untuk memberi pengertian tentang kerugian yang akan dihadapi. Sikap Kabul tersebut membuatnya dianggap sebagai orang yang munafik oleh beberapa teman sekampusnya, merupakan pola pikir yang dimiliki Kabul sewaktu masih kuliah. namun, bentuk perubahan ditunjukkan pada kalimat: itu urusan dia merupakan pola pikir Kabul yang berbeda saat masih di bangku kuliah. 
Jika semasa bangku kuliah Kabul peduli terhadap sikap orang lain, namun pada kutipan tersebut, Kabul seakan-akan tidak peduli dengan apa yang dialami oleh atasannya. Jika dilihat lagi, nampak kedewasaan yang dialami Kabul membuat pola pikirnya berubah sehingga tidak mau untuk mencampuri urusan orang lain.

Kalimat: Karena kemiskinan terkait erat dengan struktur maupun kultur masyarakat, menghilangkannya harus melibatkan semua orang dalam semangat setia kawan yang tinggi menunjukkan bahwa Kabul beranggapan, kehidupan masa lalu yang terkait oleh kemiskinan, tidak semestinya dibalas dengan sikap pragmatis ketika sudah mendapati kehidupan yang lebih baik. Perubahan pola pikir secara deduktif tersebut itu tergambar oleh pemikiran tokoh Kabul.

Perubahan pola pikir yang didasarkan atas intuisi juga tergambar pada kalimat tersebut, Kabul yang dulunya cenderung suka mencampuri urusan orang lain mengalami perubahan dalam berpikir. Ia malah kasihan kepada atasannya tersebut yang bersikap pragmatis dan terkesan mendendam dengan kemelaratan yang pernah dirasakan. Sebenarnya kemiskinan tak harus dibalas dengan pemikiran tersebut melainkan dengan hal-hal yang lebih berguna bagi orang lain.

-Namun betul, Kabul sendiri berpikir, apa mereka cukup dikasihani dan disetiakawani dalam bentuk kenangan romantis? Bahkan, apakah keadaan mereka akan bertambah baik bila mereka disumbang beras ketika kebanjiran, disumbang air ketika terpanggang di musim kemarau, atau diberi obat gratis ketika ada wabah muntaber? Ah, kerja karitatif seperti itu tak lebih dari kembang gula yang hanya manis sesaat dan tak akan mengatasi masalah.\|

(Ahmad Tohari, hlm. 33)

Kutipan tersebut menggambarkan bentuk perubahan pola pikir tokoh Kabul. Seperti kalimat: Apa mereka cukup dikasihani dan disetiakawani dalam bentuk kenangan romantis? yang menggambarkan pemikiran Kabul secara induktif yaitu suatu proses berpikir yang berupa kesimpulan umum atau dasar pengetahuan tentang hal-hal yang bersifat khusus. Artinya, dari fakta-fakta yang ada dapat ditarik suatu kesimpulan. Kabul berpikir bahwa orang-orang yang berada di bawah garis kemiskinan tak selalu dapat dikasihani. Karena pada hakikatnya, kemiskinan sebenarnya dapat dikurangi dengan usaha dan kerja keras. Kemiskinan yang terjadi seakan-akan merupakan warisan turun-temurun dapat diputuskan dengan perjuangan, khususnya mencapai tingkat pendidikan yang dapat mengisi peluang pekerjaan.

Kalimat: Apakah keadaan mereka akan bertambah baik? tersebut menunjukkan perubahan pola berpikir Kabul yang beranggapan bila orang-orang yang berada dalam kesukaran dan terus dibantu, tentu tidak akan mengubah keadaan mereka. Bahkan mereka akan menjadi orang-orang yang malas dan manja atas pemberian orang lain. Perubahan cara berpikir tersebut membuat rasa empati Kabul terhadap orang-orang yang melarat diragukan akibat pola pikir yang muncul karena seringnya melihat hal-hal tersebut di lingkungan sekitarnya.

Kalimat: Tak akan mengatasi masalah juga semakin menjadi realita dengan perubahan pola pikir Kabul berdasarkan penalaran deduktif yaitu penalaran yang didasarkan atas cara penarikan kesimpulan khusus dari hal-hal yang bersifat umum. Pemikiran mengenai kemelaratan tersebut seakan menjadi hal yang tabu dan menjadi sulit untuk dilepaskan dari 
kehidupan akibat pola pikir masyarakat yang selalu mengharapkan belas kasihan dari orang lain dan tak mau berusaha dan kerja keras untuk mengubah kemelaratan menjadi lebih baik.

-Niat Wati membayar makan siang membuat pikiran Kabul melebar. Ah, bagaimana bila uang Wati berasal dari gaji ayahnya yang anggota DPRD itu? Di tahun 1991 ini, Kabul sering membaca kritikan pedas terhadap para anggota dan lembaga DPRD. Secara kelembagaan, DPRD sering di cap hanya menjadi tukang stempel atau aksesori Pemerintah Orde Baru. Amanat rakyat pemilih kurang tersalur dan lebih banyak menjadi bahan retorika para politikus.

(Ahmad Tohari, hlm. 56)

Perubahan pola pikir secara induktif yang ditunjukkan Kabul terdapat pada kalimat: Bagaimana bila uang Wati berasal dari gaji ayahnya yang anggota DPRD itu? menunjukkan perubahan pola pikir Kabul ketika Wati ingin membayar makan siang. Pola pikir induktif merupakan penarikan kesimpulan yang bersifat umum pada hal-hal yang bersifat khusus. Artinya, dari fakta-fakta yang ada dapat ditarik suatu kesimpulan. Kabul yang sebenarnya menyukai Wati, harus menahan perasaannya karena Wati merupakan anak dari seorang anggota legislatif. Karena Kabul beranggapan pada zaman tersebut. Para anggota legislatif dianggap hanya menjadi sampul dari pemerintahan yang hanya duduk manis di dalam gedung dan dianggap banyak menggunakan uang rakyat.

Perubahan pola pikir Kabul terlihat pada kalimat: Amanat rakyat pemilih kurang tersalur dan lebih banyak menjadi bahan retorika para politikus menjadi bahan pertimbangan bagi Kabul untuk membiarkan dirinya larut dalam perasaan. Kekritisan yang dialami Kabul mengenai hal-hal yang berkaitan dengan para wakil rakyat membuatnya harus membiarkan Wati kecewa terhadap perubahan pemikirannya tersebut. Karena wakil rakyat yang seharusnya menjadi pembela aspirasi rakyat, malah menjadikan amanat rakyat yang dijanjikan untuk disampaikan hanya sebagai bahan retorika yang tidak ada realisasinya.

Kutipan yang juga menggambarkan perubahan pola pikir tokoh Kabul sebagai berikut.

- Mutu jembatan yang harusnya berdiri dengan mutu standar, malah saya biarkan diabaikan. Saya merasa bahwa telah mengkhianati ilmu pengetahuan yang didapat. Begini. Semua insinyur sipil, tak terkecuali saya, tahu bagaimana jembatan, yang benar-benar jembatan, harus dibangun. Nah, ke-cablaka-an saya menuntut agar saya tidak mengkhianati pengetahuan itu, pengetahuan teknik sipil.\|

(Ahmad Tohari, hlm.68)

Kalimat yang menunjukkan pola pikir Kabul terdapat pada kalimat: saya merasa bahwa telah mengkhianati ilmu pengetahuan yang didapat. Kalimat tersebut menunjukkan bahwa Kabul merasa telah mengkhianati ilmu yang didapatkannya karena mutu jembatan yang berdiri di bawah standar. Bentuk perubahan pola pikir terdapat pada kalimat: saya tidak mengkhianati pengetahuan itu, menunjukkan bahwa Kabul tidak merasa mengkhianati pengetahuannya. 
Kalimat: Semua insinyur sipil, tak terkecuali saya, tahu bagaimana jembatan, yang benar-benar jembatan, harus dibangun, menggambarkan pola pikir tokoh Kabul secara induktif. Pemikiran didasarkan atas pengetahuan tersebut merujuk pada pola pikir tokoh Kabul karena ia memiliki pengetahuan mengenai struktur jembatan yang sesungguhnya. Kesimpulan umum yang diperoleh Kabul dari kasus tersebut merupakan bentuk proses berpikir dari hal-hal khusus. Maksudnya, Kabul dan sarjana sipil lainnya mengetahui ilmu yang harus mereka terapkan dalam proyek, sehingga hasil yang diperoleh seperti yang diharapkan.

Kalimat: saya tidak mengkhianati pengetahuan, merupakan gambaran pemikiran tokoh Kabul yang juga merujuk pada pola pikir secara induktif. Kabul tidak ingin mengkhianati tujuan awal sebagai sarjana sipil. Pemikiran tersebut merupakan simpulan yang didapatkan dari kasus yang dialaminya dalam proyek. Pemikiran ilmiah tersebut juga merupakan hasil yang didapatkan Kabul sebagai sarjana sipil.

Perubahan pola pikir intuisi terdapat pada kutipan berikut.

-Walaupun aku seringkali mengikuti kemauan Dalkijo, tapi untuk urusan ini aku tidak mau berkompromi. Memang. Dan untuk meliburkan pekerja, aku harus berdebat dulu dengan Pak Dalkijo. Aku tak mau jadi ujung tangan kapitalis baru yang menindas bangsa sendiri. Libur hari Minggu adalah hak mereka. Apalagi sudah dua bulan mereka bekerja tanpa libur.\|

(Ahmad Tohari, hlm. 102)

Kalimat: walaupun aku seringkali mengikuti kemauan Dalkijo, tapi untuk urusan ini aku tidak mau berkompromi, merupakan bentuk pola pikir Kabul yang kerap kali mengikuti kemauan atasannya. Namun bentuk perubahan pola pikir Kabul ditunjukkan pada kalimat: dan untuk meliburkan pekerja, aku harus berdebat dulu dengan Pak Dalkijo.

Kalimat: Aku tak mau jadi ujung tangan kapitalis baru yang menindas bangsa sendiri, merupakan bentuk gambaran pemikiran tokoh Kabul yang didasarkan atas intuisi. Intuisi merupakan bentuk pemikiran yang didasarkan atas perasaan ,emosi, dan rasa. Intuisi yang tergambar dalam kalimat tersebut merupakan bentuk luapan emosi Kabul karena para pekerja yang seharusnya diberikan libur, malah dibiarkan terus berkerja tanpa libur. Intuisi Kabul muncul ketika ia melihat kesewenang-wenangan yang dilakukan oleh pemilik proyek untuk memaksa para pekerja lembur agar proyek segera terselesaikan.

Kalimat: Libur hari Minggu adalah hak mereka. Apalagi sudah dua bulan mereka bekerja tanpa libur, juga merupakan bentuk perubahan pola pikir Kabul berdasarkan intuisi. Intuisi yang ditunjukkan pada kalimat tersebut, memacunya untuk menggunakan hati nurani walaupun ia harus berdebat dengan atasannya demi meliburkan para pekerja.

\section{Perubahan Sikap Tokoh Kabul dalam Novel Orang-Orang Proyek Karya Ahmad Tohari}

Perubahan sikap merupakan hal yang sering dialami dalam kehidupan sehari-hari dan biasanya dapat terjadi ketika seseorang telah mengalami perubahan maupun peningkatan sosial, dalam kehidupannya. Perubahan sikap dapat dilihat sebagai wujud eksplorasi diri, 
artinya perubahan sikap dapat terlihat ketika seseorang mampu menunjukkan kemampuannya di suatu bidang yang menurut orang lain bertentangan dengan kemampuan. Perubahan sikap juga berkenaan dengan faktor-faktor yang memengaruhinya, baik itu faktor eksternal maupun faktor internal. Berikut kutipan yang menujukkan perubahan sikap tokoh Kabul dalam novel Orang-Orang Proyek karya Ahmad Tohari.

-Aku berkeyakinan bahwa aku dapat bertahan hingga proyek ini selesai dikerjakan. Tapi, maaf Wat, aku memutuskan berhenti karena prinsip yang harus kubela. Aku harus pergi, namun aku minta kamu tetap bekerja sampai proyek ini selesai. Atau dianggap selesai menjelang pada HUT GLM, kira-kira sebulan lagi.\|

(Ahmad Tohari, hlm. 201)

Kalimat: aku berkeyakinan bahwa aku dapat bertahan hingga proyek ini selesai dikerjakan, merupakan bentuk sikap pasti Kabul bahwa ia dapat bertahan hingga proyek tersebut selesai. Namun, bentuk perubahan ditunjukkan pada kalimat: aku memutuskan berhenti merupakan bentuk perubahan sikap yang ditunjukkan oleh tokoh Kabul, hal ini disebabkan oleh kegiatan yang dialaminya selama memimpin proyek bertentangan dengan prinsip yang dianutnya. Walaupun ia tahu akan konsekuensi yang dihadapi ketika berhenti dari proyek tersebut.

Perubahan sikap yang dimunculkan oleh tokoh Kabul merupakan bentuk protes terhadap kinerjanya sendiri yang tidak dapat menentang kecurangan oleh pihak atasannya. Kecurangan-kecurangan yang mengatasnamakan kepentingan golongan tersebut, memaksa Kabul bersikap karena tidak sesuai dengan prinsipnya yang mengutamakan kejujuran. Perubahan sikap yang dilakukan Kabul tersebut merupakan bentuk dorongan faktor internal, sehingga ia mengambil keputusan untuk keluar dari proyek tersebut.

-Kabul sulit menahan kegelisahan yang dirasakannya. Menjauhi Wati dan perhatian yang diberikan mungkin merupakan pekerjaan yang lumayan sulit untuk dilakukan. Nasihat Basar agar Kabul tidak memberi harapan kepada Wati tak pernah dilupakan. Maka Kabul membuat dirinya selalu ada acara bila malam Minggu Wati mengajaknya nonton bareng. Majalah kesukaan dibeli di hari pertama terbit, sehingga tak ada peluang bagi Wati untuk memasoknyall

(Ahmad Tohari, hlm. 112)

Sikap yang ditunjukkan pada kalimat: Kabul sulit menahan kegelisahan yang dirasakannya, merupakan bentuk gejolak yang sulit ditahan oleh Kabul. Namun bentuk perubahan sikap ditunjukkan pada kalimat: nasihat Basar agar Kabul tidak memberi harapan kepada Wati tak pernah dilupakan. Maka Kabul membuat dirinya selalu ada acara bila malam Minggu Wati mengajaknya nonton bareng. Perubahan sikap yang ditunjukkan oleh Kabul tersebut merupakan bentuk dorongan oleh faktor eksternal, yang didapat oleh Kabul berasal dari nasihat sahabatnya.

Menyibukkan diri sendiri merupakan bentuk perubahan sikap yang ditunjukkan oleh Kabul. Perubahan itu terjadi karena Kabul juga tak ingin membuat hubungan Wati dan kekasihnya menjadi renggang, karena Wati merasa Kabul juga menyukai segala bentuk perhatian yang ditunjukkannya.

Selain itu, kalimat yang juga menyatakan bentuk perubahan sikap oleh Kabul majalah kesukaan dibeli di hari pertama terbit merupakan hal yang sengaja dilakukan agar Wati tidak mempunyai peluang untuk memberinya perhatian. Segala sesuatu yang dibutuhkan oleh 
Kabul, sengaja dipersiapkan sendiri agar perubahan sikap tersebut tidak semata-mata menjadi perubahan yang bersifat sementara. Melainkan agar Wati berhenti untuk mendekatinya dan memberi perhatian yang berlebihan.

-Kami akan memberikan bahan-bahan bangunan bila jembatan itu sudah selesai dikerjakan. Sar, eh Saudara Kades, situ sudah dengar kami ingin jembatan ini selesai dengan mutu baik. Artinya, bahan-bahan bangunan tidak bisa dikurangi untuk tujuan lain."

-Untuk sebuah masjid sekalipun?\|| sodok Baldun.

-Ya! Jawab Kabul lugas. "masjid adalah sebuah bangunan suci dan sebagai orang Islam saya merasa wajib menyumbangkannya. Namun, karena kesuciannya, pembangunan sebuah masjid harus tertib dan pakai tata karma. Semua material di sini kan, dibeli untuk membangun jembatan, bukan yang lain.”

(Ahmad Tohari, hlm. 139-140)

Kalimat: kami akan memberikan bahan-bahan bangunan bila jembatan itu sudah selesai dikerjakan, merupakan bentuk sikap Kabul yang akan memberikan bahan-bahan sesuai dengan permintaan pihak GLM. Namun, perubahan sikap ditunjukkan pada kalimat: artinya, bahanbahan bangunan tidak bisa dikurangi untuk tujuan lain, merupakan bentuk perubahan sikap Kabul karena menginginkan mutu jembatan itu berdiri dengan baik sehingga tidak dapat memberikan bahan bangunan yang diminta.

Kutipan di atas menggambarkan perubahan sikap tokoh Kabul. Walaupun ia merupakan seorang muslim yang taat dan merasa wajib menyumbangkan untuk kepentingan masjid, ia mengubah sikapnya demi tanggung jawab yang diembannya. Kabul bersikap agar kepentingan masjid menjadi prioritas kedua setelah pembangunan jembatan. Karena pembangunan jembatan merupakan hal yang penting mengingat bahan yang digunakan sangat minim akibat anggaran biaya yang dibatasi.

Hal itulah yang membuat Kabul bersikap seakan-akan tidak peduli pada kepentingan masjid. Perubahan yang terjadi akibat faktor eksternal dan internal tersebut membuat Kabul harus bersikap lebih tegas demi kelancaran proyek yang dipimpinnya.

Dorongan faktor eksternal yang mengubah sikap Kabul yaitu karena mengetahui terjadinya korupsi dari anggaran biaya oleh beberapa pihak. Sehingga membuatnya menutup nurani sesaat terutama dalam permintaan bantuan material mengenai renovasi masjid di daerah proyek tempat ia bekerja. Sedangkan faktor internal yang melatarbelakangi perubahan sikapnya yaitu adanya beban moral bila proyek ini tidak diselesaikan dengan mutu yang sesuai sehingga rakyat tidak harus menanggung hutang negara akibat rusaknya bangunan yang tentunya memerlukan biaya besar.

-Kabul sering merasa iba bila melihat orang lain dalam kesusahan bahkan seringkali berniat untuk membantunya. Bergembira di atas kesusahan orang lain adalah hal yang tidak disukai Kabul. Anehnya, itulah yang terjadi ketika dia baru saja menerima pembicaraan lewat radio. Ir. Dalkijo boleh marah besar, karena derek yang dipesannya terperosok ke dalam parit ketika melewati jembatan yang sedang dan sudah berkali-kali diperbaiki selepas Kota Cirebon. Karena mengalami kerusakan, 
derek itu tak mungkin bisa bekerja dalam waktu dekat. Jadi, selagi atasannya kecewa luar biasa, Kabul malah merasa plong.

(Ahmad Tohari, hlm. 158-159)

Kalimat: Kabul sering merasa iba bila melihat orang lain dalam kesusahan bahkan berniat untuk membantunya, merupakan sikap dasar Kabul yang mudah iba bila melihat orang lain dalam kesusahan. Namun, bentuk perubahan sikap yang ditunjukkan oleh Kabul dalam kutipan tersebut adalah: bergembira di atas kesusahan orang lain adalah hal yang tidak disukai Kabul merupakan bentuk sikap Kabul yang sebenarnya, namun karena faktor ekternal dan internal yang membuat sikapnya jadi berubah dan ditunjukkan pada kalimat: Anehnya, itulah yang terjadi ketika dia baru saja menerima pembicaraan lewat radio. Kegembiraan yang ditunjukkan Kabul merupakan bentuk perubahan sikapnya terhadap masalah yang dihadapi oleh atasannya tersebut.

Sikap Kabul yang menjunjung tinggi mutu bangunan, malah ditentang oleh atasannya dengan mendatangkan derek untuk segera memasang balok pada tiang jembatan yang belum mengeras. Namun, hal tersebut berubah ketika ia mendapat kabar bahwa derek yang dikirim oleh atasannya tersebut mengalami kendala sehingga tiang jembatan dapat mengeras dan balok dapat dipasang pada waktunya. Hal itulah yang menyebabkan sikap Kabul berubah, bila awalnya tidak suka bila bahagia di atas penderitaan orang lain, malah menjadi sebaliknya karena faktor tersebut.

Kutipan yang juga menunjukkan bentuk perubahan sikap yang dialami oleh tokoh Kabul adalah sebagai berikut.

-Ya, kamu benar. Kekhawatiran itu ada. Namun lebih berat bila aku harus menyerahkan kepada masyarakat jembatan yang tidak bermutu. Aku akan merasa siasia jadi insinyur bila jembatan yang ku buat hanya bisa dipakai satu-dua tahun, kemudian harus diperbaikill.

-Andaikata Mas benar-benar memutuskan berhenti, lalu?॥

-Aku ingin jadi dosen, meskipun harus kuliah lagi. Kerja di lapangan ternyata kurang cocok untukku karena banyak urusan nonteknik yang merongrong.\|

(Ahmad Tohari, hlm. 151)

Dorongan faktor eksternal juga memengaruhi perubahan sikap seseorang dan ditunjukkan pada kalimat: Aku ingin jadi dosen, meskipun harus kuliah lagi. Kerja di lapangan ternyata kurang cocok untukku karena banyak urusan nonteknik yang merongrong tersebut merupakan bentuk perubahan sikap tokoh Kabul. Kabul yang merasa bahwa realita di lapangan yang dihadapinya ternyata jauh berbeda dengan ilmu yang didapatnya selama di bangku kuliah. Bila selama menempuh pendidikan Kabul diajarkan untuk menerapkan ilmu yang didapat secara benar terhadap proyek yang dipegang, maka dalam proyek yang dipimpinnya ternyata ia sulit menerapkan ilmu tersebut.

Keadaan teknis di lapangan yang memaksanya harus berhenti karena bertentangan dengan ilmu yang didapat membuatnya merelakan proyek yang dipimpinnya untuk dilepas 
demi menjaga nama baik gelar yang diperolehnya. Selain itu, ia juga tidak mungkin memaksakan hati nuraninya untuk melanjutkan proyek yang tidak sesuai dengan prinsipnya.

-Wah Dik Kabul, terima kasih atas peringatan ini. Lagipula Dik Kabul tahu bagaimana efektivitas hukum di negeri ini. Penegakannya amburadul. Maka banyak orang bilang di sini hukum dibuat hanya untuk dilanggar. Iya kan?\|

-Iya, saya tahu. Meskipun begitu saya tidak mau menggunakan besi bekas itu. Bila dipaksakan, lebih baik saya mengundurkan diri.\|

(Ahmad Tohari, hlm. 182)

Kalimat: Meskipun begitu saya tidak mau menggunakan besi bekas itu. Bila dipaksakan, lebih baik saya mengundurkan diri, merupakan bentuk perubahan sikap yang didasarkan oleh faktor eksternal yang dialami tokoh Kabul. Ia merasa bahwa penggunaan besi bekas tidak dapat menunjang mutu jembatan yang sedang dibangun. Selain itu, karena atasan memaksakan menggunakan besi bekas untuk tambahan bahan struktur jembatan membuat Kabul mengubah sikapnya dengan menentang perintah tersebut.

Perubahan sikap Kabul yang ditunjukkan pada kalimat: Bila dipaksakan, lebih baik saya mengundurkan diri, menunjukkan bentuk perubahan sikap Kabul. Faktor eksternal dari lingkungan membuatnya merasa tidak nyaman, sehingga ia mengambil tindakan tegas dengan ancaman mengundurkan diri. Tindakan tersebut merupakan bentuk perubahan yang dipengaruhi oleh paksaan atasannya.

Bila dilihat lagi, pada kalimat tersebut juga menggambarkan perubahan yang didasarkan oleh faktor internal. Paksaan yang tidak rasional tersebut membuat Kabul dengan tegas menyatakan ancaman mengundurkan diri. Karena perintah dari atasan tersebut bertentangan dengan prinsipnya yang mengutamakan mutu demi menerapkan ilmu yang didapatkan di bangku kuliah.

—Jadi, sekali lagi, turutilah nasihat kakak angkatanmu ini. Selesaikanlah proyek ini seperti yang kami mau. Atau, apakah Dik Kabul mau repot menghadapi pemeriksaan aparat keamanan?\|

Tenang. Kabul tampak sangat tenang. Dan dia sebenarnya sudah menyediakan cukup kata-kata untuk menanggapi tekanan Dalkijo. Namun, Kabul memilih diam sejenak. Dari tempat duduknya, Wati mengikuti dengan saksama pembicaraan itu. Wajahnya kadang tampak tegang, kadang tampak sedih. Ingin ikut bicara. Tapi apa?

-Terima kasih atas nasihat Pak Dalkijo. Untuk mereka yang suka gampangandan ingin serba mudah, nasihat Bapak tentu pas. Dan maaf, Pak, saya bukan kalangan seperti itu. Jadi saya memilih mengundurkan diri terhitung sejak hari ini.\|

(Ahmad Tohari, hlm. 200)

Kutipan di atas menggambarkan bentuk perubahan sikap yang ditunjukkan oleh tokoh Kabul dengan dorongan faktor internal dan eksternal. Kalimat: Tenang. Kabul tampak sangat tenang. Dan dia sebenarnya sudah menyediakan cukup kata-kata untuk menanggapi tekanan Dalkijo, merupakan bentuk perubahan sikap yang didasarkan oleh faktor internal. 
Pembawaan Kabul yang seharusnya emosi karena atasannya tidak mau mengikuti permintaan tersebut, menjadikan perubahan sikap yang ditunjukkan berbeda. Pembawaan sikap tenang yang ditunjukkan tokoh Kabul merupakan bentuk perubahan didasarkan oleh dorongan faktor internal.

Selain itu, bentuk perubahan sikap yang ditunjukkan Kabul oleh dorongan faktor internal terdapat pada kalimat: Untuk mereka yang suka gampangan dan ingin serba mudah, nasihat Bapak tentu pas. Dan maaf, Pak, saya bukan kalangan seperti itu. Pada kalimat tersebut, Kabul menyatakan tidak mau mengikuti sikap orang lain yang mudah disuap dengan cara-cara pragmatis. Kabul lebih mementingkan mutu jembatan, sehingga jembatan dapat bertahan lama. Keinginan atasannya tersebut juga bertentangan dengan prinsip sebagai seorang sarjana sipil yang mengutamakan mutu bangunan.

Perubahan sikap yang ditunjukkan oleh Kabul didasarkan atas faktor eksternal terdapat pada kalimat: Jadi saya memilih mengundurkan diri terhitung sejak hari ini. Kalimat tersebut menunjukkan perubahan sikap Kabul yang merujuk pada tindakan tegas. Permintaan atasan yang bertentangan dengan prinsipnya, membuat Kabul harus mengambil tindakan tegas, yaitu mengundurkan diri.

Selain itu, permintaan atasannya, Dalkijo tidak dapat diterima mengingat bahwa mengabaikan mutu bangunan merupakan salah satu bentuk pengkhianatan terhadap ilmu pengetahuan yang sudah didapatkan. Pada kutipan tersebut juga menggambarkan bentuk perubahan sikap yang nyata ditunjukkan Kabul akibat dorongan faktor internal dan eksternal.

\section{SIMPULAN DAN SARAN}

Perubahan pola pikir tokoh Kabul dalam novel Orang-Orang Proyek karya Ahmad Tohari dilatarbelakangi oleh dua hal, yaitu perubahan pola pikir akibat faktor penalaran (berupa deduktif dan induktif). Pola pikir deduktif adalah proses berpikir dengan cara menarik kesimpulan khusus dari hal-hal yang bersifat umum. Pola pikir induktif adalah proses berpikir dengan cara menarik kesimpulan umum dari hal-hal yang bersifat khusus, serta faktor intuisi merupakan faktor yang berdasarkan perasaan, emosi, atau rasa.

Perubahan sikap tokoh Kabul dalam novel Orang-Orang Proyek karya Ahmad Tohari dilatarbelakangi oleh dua hal. Pertama, faktor eksternal yang merupakan dorongan dari luar atau sosialnya. Kedua, faktor internal yang berasal dari dalam dirinya.

Data gambaran perubahan pola pikir dan sikap tokoh Kabul dalam novel Orang-Orang Proyek karya Ahmad Tohari berjumlah lima belas kutipan. Pada perubahan pola pikir terdapat delapan kutipan dengan rincian: tiga kutipan menggambarkan pola pikir secara intuisi, dua kutipan menggambarkan perubahan pola pikir secara deduktif dan dua kutipan juga menggambarkan perubahan pola pikir secara induktif, serta satu kutipan menggambarkan perubahan pola pikir secara deduktif-induktif. Pada perubahan sikap terdapat tujuh kutipan dengan rincian: perubahan sikap yang didasarkan atas faktor internal terdapat pada satu kutipan, perubahan sikap yang didasarkan atas faktor eksternal tergambar pada dua kutipan, dan empat kutipan yang menggambarkan perubahan sikap disebabkan oleh faktor eksternalinternal.

Peneliti ini hanya membahas tentang perubahan pola pikir dan sikap tokoh Kabul dalam novel Orang-Orang Proyek karya Ahmad Tohari. Selain aspek tersebut, masih ada cara lain untuk meninjau suatu novel yang berkaitan dengan nilai sosial di dalamnya, misalnya ditinjau dari perubahan pola berpikir dan sikap yang ditunjukkan oleh seseorang 
yang sudah mengalami peningkatan strata, baik pendidikan maupun jabatan. Hal tersebutlah yang diharapkan oleh peneliti untuk diungkapkan oleh peneliti selanjutnya agar penelitian yang berkaitan dengan analisis perubahan pola pikir dan sikap tokoh utama dalam novel ini menjadi lebih lengkap.

\section{REFERENSI}

Aminuddin. 2000. Pengantar Apresiasi Karya Sastra. Bandung: Sinar Baru Algesindo Offset.

Mayang, Reny Yulianti. 2012. Analisis Perubahan Pola Pikir dan Perubahan Sikap Tokoh Kabul dalam Novel Orang-Orang Proyek Karya Ahmad Tohari untuk Meningkatkan Kemampuan Menganalisis Unsur Intrinsik dan Ekstrinsik Novel Indonesia pada Siswa Kelas XI IPA 2 Semester 1 Tahun Pembelajaran 2012/2013 SMA Negeri 3 Palangkaraya. Palangkaraya: FKIP UNPAR.

Riawati. 2010. Analisis Prinsip Maksim Formal Tokoh Protagonis dalam Novel Harimau! Harimau! Karya Mochtar Lubis untuk Meningkatkan Memahami Teks Sastra Siswa Kelas XI IPS 3 Semester II Tahun Pembelajaran 2010/2011 SMA Negeri 4 Palangkaraya. Palangkaraya: FKIP UNPAR.

Semi, M. Attar. 1990. Metode Penelitian Sastra. Bandung: Angkasa.

Tohari, Ahmad. 2007. Orang-Orang Proyek. Jakarta: PT. Gramedia Pustaka Utama. 